
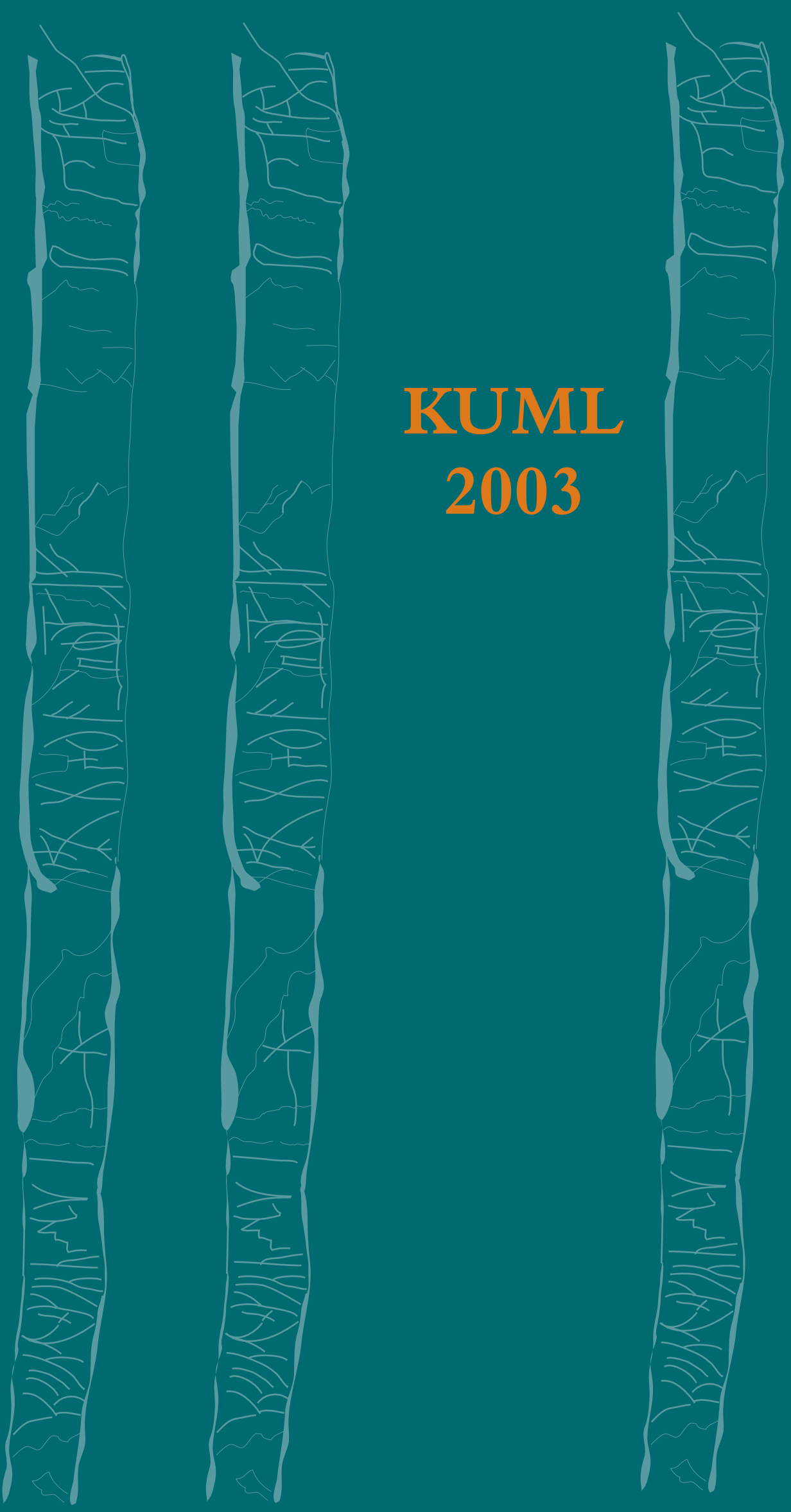


\section{KUML 2003}

Årbog for Jysk Arkæologisk Selskab

With summaries in English

I kommission hos Aarhus Universitetsforlag 


\section{Ravning-broens alder \\ En af Danmarks sikreste dendrokronologiske dateringer?}

Netop i begyndelsen af 1970'erne, hvor udgravningen af den store vikingetidsbro over Vejle ådal begyndte, blev den dendrokronologiske dateringsmetode for alvor taget i brug i Danmark. ${ }^{1}$ Det var derfor naturligt, at der blev indsendt prøver til årringsmåling fra Ravning-broen, og i 1977 kunne udgraveren berette, hvordan den nye metode kom på en prøve, som den bestod med glans: "De stolper, der havde splintved bevaret, viste entydigt, at broen er bygget 979 eller dog ganske tæt deromkring «. ${ }^{2}$ Udgravningerne af broanlægget fortsatte, men den dendrokronologiske datering blev ikke diskuteret; den blev anset for at ligge fast til trods for den anførte usikkerhed: „Ravning-broens datering er blandt de sikreste fra Danmarks vikingetid. Knap 100 dendrokronologiske dateringer af brotømmerstykker foreligger, og de udpeger 979 eller 980 som fældningsåret for egetræerne «. ${ }^{3}$ Senest er broens datering blevet yderligere præciseret: »Mellem oktober år 979 og april år 980 opførtes broen over Ravning Enge«. ${ }^{4}$

De citerede udsagn gengiver den herskende opfattelse af Ravning-broens alder. De viser samtidig den stigende sikkerhed og præcision, hvormed den dendrokronologiske datering af broen er fremlagt gennem årene - til trods for, at alle udsagnene i alt væsentligt bygger på de samme dateringsresultater, som den første meddelelse fra Thorkild Ramskou i 1977.

I realiteten er dateringen dog langt fra så velunderbygget og så præcis, som citaterne giver indtryk af. Der er til i dag (maj 2002) kun udført årringsmåling på 25 prøver fra Ravning-broen. Af disse er 20 dateret. Heraf mangler 16 prøver imidlertid hele splinten og måske et uvist antal kerneårringe. Kun fire af de daterede prøver omfatter splintved, og ingen har med sikkerhed bevaret barkringen, træets yngste årring lige under barken. Uanset de citerede udsagn er der altså ikke en eneste af de undersøgte prøver, der giver et præcist årstal for træernes fældning og Ravning-broens opførelse.

At det forholder sig sådan, vil den følgende fremlæggelse forhåbentlig vise. Samtidig skal der redegøres for, hvad de foreliggende dendrokronologiske dateringer realistisk set oplyser om broens opførelsestidspunkt. 


\section{Træprøverne}

Den første prøve fra Ravning-broen, som blev indsendt til Nationalmuseet, var en stolpe, som blev trukket op af lodsejeren i $1971 .{ }^{5}$ Den blev årringsmålt, og en C14-datering af de yngste bevarede årringe viste, at broen var fra vikingetiden. På denne baggrund udførte Th. Ramskou udgravninger af broanlægget i 1972-78, og 57 træprøver blev efterfølgende indsendt til årringsmåling. Efter Ramskous død i 1982 lå gravearbejdet stille en årrække, men nye undersøgelser ved Mogens Schou Jørgensen blev udført i 1993-96. Herfra blev indsendt ca. 40 prøver til årringsmåling. Tilsammen er altså indsendt omkring 100 prøver fra Ravning-broen til dendrokronologisk datering på Nationalmuseet. Kun 23 prøver, alle fra Ramskous udgravninger, er imidlertid blevet årringsmålt. Herudover er der på Nationalmuseet målt og dateret to prøver fra broen, som befinder sig på Vejle Museum. ${ }^{6}$

I begyndelsen af 1970'erne rådede Nationalmuseet ikke over en fast ansat dendrokronolog, og der var derfor indgået den aftale, at museet indsamlede træprøver, mens årringsmåling og datering blev udført af Dieter Eckstein på det dendrokronologiske laboratorium i Hamburg. Dette skete også for flertallet af Ravning-prøverne. I alt 18 prøver blev årringsmålt, og sammen med måleværdierne fra den i 1971 indsendte stolpe, dateret i Hamburg, 16 med positivt resultat. Kun seks prøver er både målt og dateret på Nationalmuseet.?

\section{Dateringerne}

Resultaterne af målingen og dateringen af prøverne fra Ravning-broen fremgår af tabel 1. Tabellen omfatter kun 22 af de 25 undersøgte prøver, idet tre prøver $^{8}$ er udeladt på grund af usikkerheder ved årringsmålingen eller prøvernes herkomst. Ingen af disse tre prøver har spillet en rolle ved fastlæggelse af broens bygningsår. Fig. 1 viser den tidsmæssige fordeling af de daterede prøver.

For de prøver, der er undersøgt i Hamburg, er det ikke muligt umiddelbart at verificere de anførte dateringer; måleværdierne for de enkelte prøver findes nemlig - i hvert fald på Nationalmuseet - kun i form af håndtegnede kurver for (de fleste) af de målte radier. Der er dog ingen grund til at antage, at dateringerne er fejlbehæftede; mange års samarbejde med laboratoriet i Hamburg har vist, at resultater herfra er særdeles pålidelige. De dateringer, der senere er udført på Nationalmuseet, kan også anses for fuldt pålidelige.

Af tabel 1 ses, at den yngste bevarede splintårring på de undersøgte prøver findes på stolpe nr. 26 og er dannet i år 979; fældningen af dette træ 


\begin{tabular}{|c|c|c|c|c|c|c|}
\hline Herkomst & $\begin{array}{l}\text { Funktion } \\
\text { Function }\end{array}$ & $\begin{array}{l}\text { Prøvenr. } \\
\text { år til marv } \\
\text { Sample no. }\end{array}$ & $\begin{array}{l}\text { Marv eller antal } \\
\text { i alt } \\
\text { Pith or no. of } \\
\text { years to pith }\end{array}$ & $\begin{array}{l}\text { Antal årringe } \\
\text { splintårringe } \\
\text { Total no. of } \\
\text { tree rings }\end{array}$ & $\begin{array}{l}\text { Antal } \\
\text { datering } \\
\text { No. of rings } \\
\text { in sapwood }\end{array}$ & $\begin{array}{l}\text { Årringsseriens } \\
\text { datering } \\
\text { Dating of the tree } \\
\text { ring sequence }\end{array}$ \\
\hline Optaget 1971 & Lodret stolpe & (D 303) * & Min. ca. 100 & 293 & - & $620-912$ \\
\hline Udgravning 1972 & Skråstolpe & Nr. 1 (D 514) & Ca. 20 & 179 & - & $615-793$ \\
\hline- & Lodret stolpe & Nr. 2 (D 515) & Ca. 50 & 199 & - & - \\
\hline - & Lodret stolpe & Nr. 3 (D 516) & Nær M & 199 & - & - \\
\hline- & Lodret stolpe & Nr. 4 (D 517) & $M$ & 116 & - & $777-892$ \\
\hline- & Lodret stolpe & Nr. 7 (D 520) & M & 183 & - & $717-899$ \\
\hline- & Lodret stolpe & Nr. 11 (D 524) & Ca. 2 & Ca. $130+133$ & 8 & $709-971$ \\
\hline- & Lodret stolpe & Nr. 12 (D 525) & $M$ & 148 & - & $738-885$ \\
\hline- & Lodret stolpe & Nr. 14 (D 527) & Ca. 5 & 182 & - & $677-858$ \\
\hline- & Lodret stolpe & Nr. 16 (D 529) & $?$ & 164 & $24 / 19$ & $815-978$ \\
\hline- & Lodret stolpe & Nr. 21 (D 531) * & $M$ & 206 & - & $741-946$ \\
\hline- & Skråstolpe & Nr. 22 (D 532) & $M$ & 197 & - & $671-867$ \\
\hline- & Skråstolpe & Nr. 23 (D 533) & Ca. 2 & 185 & - & $711-895$ \\
\hline- & Lodret stolpe & Nr. 24 (D 534) & Ca. 2 & 295 & - & $614-908$ \\
\hline- & Lodret stolpe & Nr. 25 (D 535) & Ca. 5 & 294 & - & $662-955$ \\
\hline- & Lodret stolpe & Nr. 26 (D 536) & $(\mathrm{M})$ & 196 & $16 / 15$ & $784-979$ \\
\hline Udgravning 1973 & $?$ & Nr. $36 \mathrm{~S}^{*}$ & $M$ & 243 & - & $505-747^{*}$ \\
\hline- & $?$ & Nr. $39 \mathrm{~N}^{*}$ & $\mathrm{M}$ & 259 & - & $677-935$ * \\
\hline- & $?$ & Nr. $40 \mathrm{~N}$ & (M) & Ca. $108+117$ & $18 / \max .13$ & (Ca.) 753-977 \\
\hline- & $?$ & Nr. $42 \mathrm{~N}$ & Ca. 2 & 190 & - & $745-934$ \\
\hline Vejle Museum & $?^{\star \star}$ & KHM 6126 (D 2769) * & Min. ca. 25 & 91 & - & $823-911$ * \\
\hline- & $? ?^{\star \star}$ & KHM 6127 (D 2768) * & Ca. 2 & 147 & - & $695-835$ * \\
\hline
\end{tabular}

Tabel 1. Oversigt over årringsmålte prøver fra Ravning-broen. Tabellen omfatter 22 prøver, målt og dateret på det dendrokronologiske laboratorium i Hamburg eller på Nationalmuseet i København. Indholdet af de enkelte kolonner i tabellen er forklaret nedenfor.

Herkomst: Hvordan og hvornår prøven er fremkommet. Funktion: Om prøven er fra en lodret eller en skrå stolpe eller funktionen er uvis. Prøvenr.: Udgravningsnummer som oplyst ved indsendelse til Nationalmuseet. Evt. magasinnummer er anført i parentes. Marv eller antal år til marv: $\mathrm{M}=$ marv til stede, $(\mathrm{M})=$ ældste målte årring tæt ved marven, ? = afstand til marv uvis, tal = skønnet antal år fra ældste målte/talte årring til marven. Antal årringe $i$ alt: Summen af målte og evt. talte årringe (antal årringe fra den ældste målte/talte årring til marven ikke medregnet). Antal splintårringe: Hvis der er forskelligt antal på de målte radier, er alle værdier anført, idet antallet af splintårringe er regnet fra det første splintår på den pågældende radius til den sidste påviste årring på prøven. - = splint mangler. Årringsseriens datering: Årstallet for ældste og yngste årring på prøven. ^) Målt/dateret på Nationalmuseet, alle andre prøver målt/dateret på laboratoriet i Hamburg. ${ }^{\star \star}$ ) Ikke en lodret brostolpe.

Origin: Context and date when the sample was taken. Function: Whether the sample comes from a vertical (lodret) or a slanting (skrå) post, or whether the function is uncertain. Sample no.: The excavation number as given in the report to the NNU (Scientific Department of the National Museum). Storage numbers are in brackets. Pith or number of years to pith: $\mathrm{M}=$ pith is present, $(\mathrm{M})=$ earliest measured tree ring near the pith, ? = the distance from the pith is unknown, number = estimated number of years from the earliest measured/counted tree ring to the pith. Total number of tree rings: the sum of measured or counted tree rings (not including the number of rings from the earliest measured/counted ring to the pith). Number of tree rings in sapwood: in cases where the measured radii give different numbers, all values have been indicated, since the number of sapwood rings is calculated from the first sapwood year on the radius in question to the last preserved tree ring on the sample. $-=$ the sapwood is missing. Dating of the tree ring sequence: the years of the earliest and latest tree rings in the sample. ${ }^{\star}$ ) Measured/dated at NNU. All other samples were measured/dated in the Hamburg laboratory. $\left.{ }^{\star \star}\right)$ Not a vertical post. 


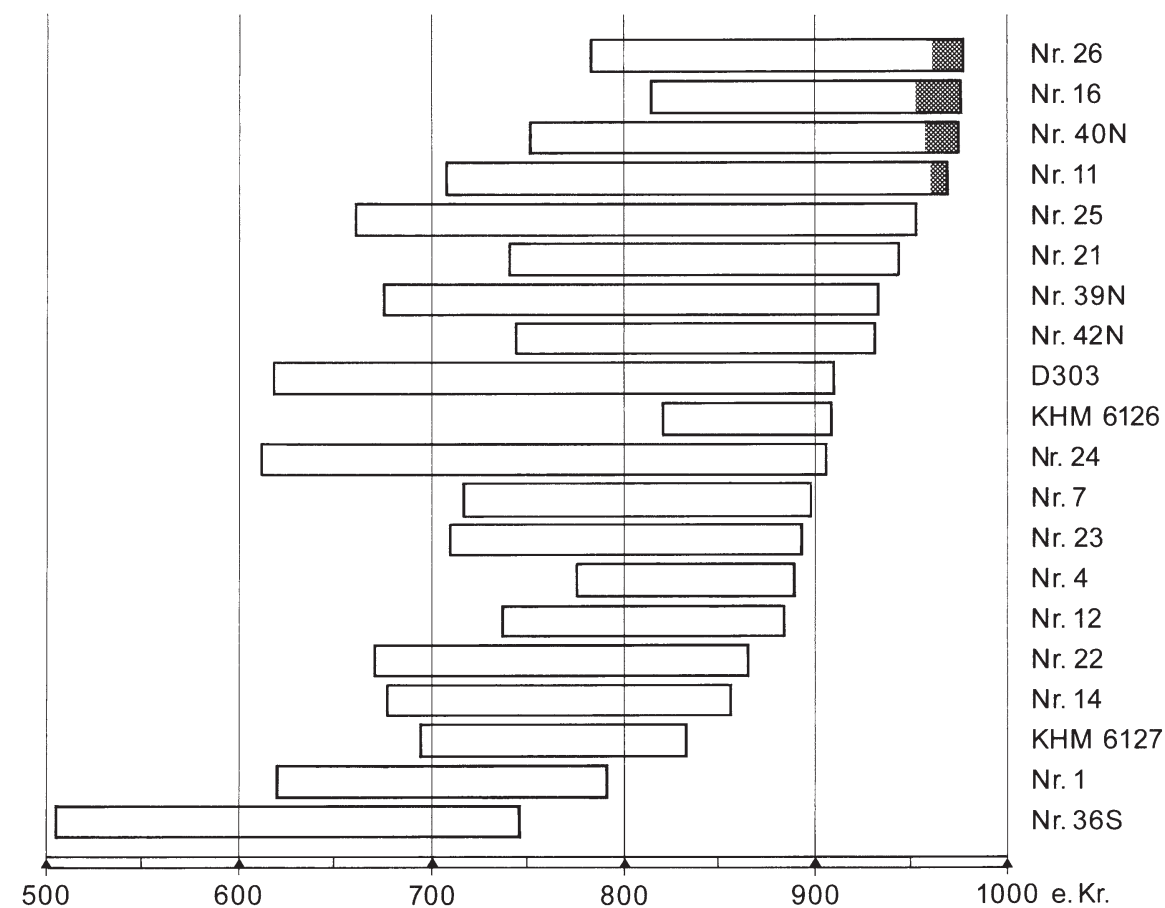

Fig. 1. Dateringen af tømmeret fra Ravning-broen. Hver bjælke repræsenterer den målte og evt. talte årringsserie fra én brostolpe, hvis udgravnings- eller magasinnummer er anført i kolonnen til højre. Bevaret splintved på prøverne er vist med raster (markeringen angiver det højeste antal splintår, der er målt på prøverne, jf. tabel 1).

The dating of the timber from Ravning Bridge. Each bar represents the measured and in some cases counted series of tree rings from one single post, with the excavation number or storage number given in the column to the right. Preserved sapwood on the samples is indicated with shading (the shading indicates the highest number of sapwood rings measured on the samples, cf. table 1).

og opførelsen af broen kan altså tidligst være sket i efteråret 979. Da der ikke er bark på prøverne fra stolpen, er det imidlertid uvist, om den yngste påviste årring er den sidste, der blev dannet i træets levetid; det kan ikke udelukkes, at der mangler en eller flere årringe på prøverne, og at træet altså er fældet på et senere tidspunkt.

For de fire prøver, der omfatter splintved, kan det sandsynlige fældningsår imidlertid fastlægges, om end med en vis usikkerhed, da antallet af splintårringe på egetræer varierer inden for ret snævre grænser. De oprindeligt beregnede fældningsår for disse prøver fremgår af en oversigt fra Hamburg-laboratoriet fra september 1975: 


$\begin{array}{lccll}\text { Stolpe nr. 26 } & \text { fældningsår } & 983-4 /+5 & \approx & 979-988 \\ \text { Stolpe nr. 16 } & - & 978-0 /+1 & \approx & 978-979 \\ \text { Stolpe nr. 40 N } & - & 979-2 /+5 & \approx & 977-984 \\ \text { Stolpe nr. 11 } & - & 983-5 /+5 & \approx & 978-988\end{array}$

De anførte årstal er fundet ved at antage, at træerne har haft $20+/-5$ splintårringe, hvilket blev anset for normalt for egetræer, der er 100-200 år gamle. +/- 5 år er dog ikke en absolut grænse for antallet af splintårringe, men et interval, inden for hvilket de fleste egetræer af denne alder falder; der er intet til hinder for, at enkelte træer har haft flere eller færre splintår end anført. At den nedre eller øvre grænse undertiden er angivet som mindre end fem år skyldes, at de på prøven forekommende årringe rækker ind over de teoretiske interval-grænser.

Tilsammen viser de faktisk forekommende årringe og de beregnede fældningsår, som fremlagt af Hamburg-laboratoriet i 1975, at fældningen af brotømmeret tidligst kan være sket i år 979, og antagelig er sket $i$ et af årene 979-988; et endnu yngre fældningsår kan dog ikke udelukkes. De prøver, der senere er dateret på Nationalmuseet, føjer intet hertil.

At »broen er bygget 979 eller dog ganske tæt deromkring«, som anført i Th. Ramskous første artikel om Ravning-broen, ${ }^{9}$ svarer godt til dette resultat, dog med den præcisering, at bygningen ikke kan være sket før 979; Ramskous formulering bygger givetvis på drøftelser med Tage E. Christiansen, som dengang var den arkæologiske «ankermand « i det dendrokronologiske arbejde på Nationalmuseet. ${ }^{10}$ Når det som nævnt anføres i litteraturen, at brotømmeret med sikkerhed er fældet år 979 eller 980, har det derimod ikke belæg i de fremlagte dateringsresultater.

\section{Træernes alder}

Siden dateringerne fra Hamburg-laboratoriet fremkom, er der sket en betydelig forøgelse af vor viden om antallet af splintårringe i egetræ, og der er derfor grund til at overveje, om den oprindelige beregning af tømmerets fældningsår stadig er den bedst mulige. Hvilke årsager, der bestemmer antallet af splintårringe, er endnu ikke fuldt afklaret, men det er givet, at antallet stiger med træernes alder. Udgangspunktet for en vurdering af fældningsårene må derfor være alderen af de træer, der en brugt ved brobyggeriet.

For at finde træernes alder er der til de på prøverne målte og talte årringe lagt det skønnede antal årringe fra den ældste målte årring til marven og fra den yngste målte årring til fældningsåret. Afstanden til marven er anslået ud fra marvstrålernes konvergens, og omregnet til antal årringe ud 


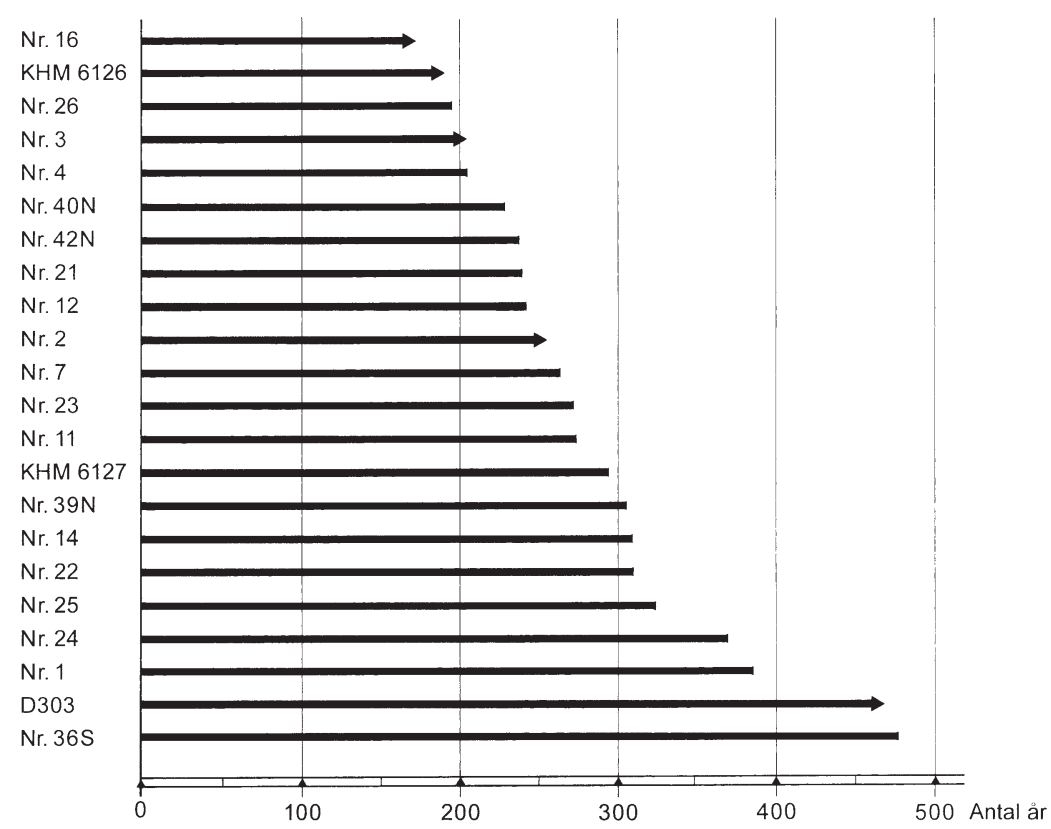

Fig. 2. Levealderen for de træer, der er brugt til brobyggeriet. Hver streg repræsenterer ét træ. Stregens længde angiver det antal årringe, der er målt og talt på prøverne fra træet plus det manglende antal årringe fra den ældste påviste årring til træets marv og fra den yngste påviste årring til træets fældningsår, som her er sat til år 980. Hvis træets årringsserie begynder med eller tæt ved marven, således at træets alder kan fastslås nogenlunde præcist (jf. tabel 1), slutter stregen brat. Hvis afstanden fra den ældste årring på prøverne til træets marv ikke har kunnet fastslås nogenlunde præcist, slutter stregen med en pil, som angiver, at træets alder er højere end stregens længde viser.

The life-span of the trees used for bridge building. Each line represents a tree. The length of the line indicates the number of tree rings measured and counted on the samples from the tree plus the number of tree rings missing from the earliest established tree ring to the pith and from the latest established tree ring to the felling year of the tree, which was in this case stated as the year 980. If the tree ring series of the tree begins with or close to the pith, so that the age of the tree may be determined rather precisely, (cf. table 1), the line ends abruptly. If it is not possible to establish the distance from the earliest tree ring to the pith with any degree of precision, the line ends with an arrow indicating that the age of the tree is greater than indicated by the length of the line.

fra middelbredden af de ældste målte årringe. I de fleste tilfælde er afstanden ganske kort; kun for fire prøver er der tale om 20 årringe eller mere. Afstanden fra den yngste årring til fældningsåret kan normalt kun beregnes, hvis prøverne omfatter splint. For Ravning-broen må det imidlertid antages, at alle træerne er fældet stort set samtidig. I beretningerne om udgravningen af broen fremhæves, at der ikke er fundet spor af reparationer, og der synes ikke at være tvivl om, at den er opført i ét stræk. ${ }^{11}$ Dette 
bekræftes også af den tidsmæssige fordeling af de yngste bevarede årringe på de daterede prøver (fig. 1), som er jævn og uden nogen gruppering, som kunne antyde flere byggefaser. ${ }^{12}$ Ved fastlæggelse af træernes alder kan vi derfor gå ud fra et fælles fældningsår, som i de her fremlagte beregninger af praktiske hensyn er sat til år 980.

De til beregning af træaldrene nødvendige data findes i tabel 1, resultatet fremgår af fig. 2. Her ses, at træerne har haft en overraskende høj alder. Ikke alene var enkelte træer næsten 500 år gamle ved fældningen, men den gennemsnitlige alder af de til brobygningen anvendte træer er tæet ved 300 år. Det er værd at bemærke, at der har været adgang til et stort antal træer af denne høje alder, og at der tilsyneladende ikke er sparet på ressourcerne ved broens opførelse.

\section{Træernes fældningsår}

Træernes alder har betydning for fastlæggelse af tømmerets fældningsår. Ved den oprindelige beregning blev det antaget, at de fire træer med bevaret splint var 100-200 år gamle; nu viser det sig, at de er en del æeldre, nemlig fra mindst 167 til ca. 274 år gamle. Det må derfor antages, at de har haft flere splintårringe og altså er fældet senere, end først beregnet. Samtidig viser en prøve uden splint (stolpe nr. 25) sig at være fra et træ, der er så gammelt, at det med tillæg for de manglende splintår også er af interesse ved bestemmelse af tømmerets fældningsår.

Til fastlæggelse af antallet af splintårringe på de fem prøver, der nu indgår i beregningen af fældningsåret, er her benyttet den på WM Trædateringslaboratoriet normalt anvendte splintstatistik; den bygger på en velunderbygget tysk statistik, ${ }^{13}$ som har vist sig anvendelig også for danske egetræer. Ved beregningen er medtaget ikke blot det samlede (højeste) antal splintårringe, der er påvist på prøverne, men det antal splintår, der er målt på de enkelte radier. Resultaterne fremgår af fig. 3 og af nedenstående tabel: $:^{14}$

$\begin{array}{lcrl}\text { Stolpe nr. 26 } & \text { fældningsår } & 987 / 988-9 /+18 & \approx 979-1006 \\ \text { Stolpe nr. 16 } & - & 976 / 981-0 /+18 & \approx 978-\geq 999 \\ \text { Stolpe nr. 40 N } & - & 985 / 990-8 /+19 & \approx 977-\geq 1009 \\ \text { Stolpe nr. 11 } & - & 991-11 /+20 & \approx 980-1011 \\ \text { Stolpe nr. 25 } & - & \geq 986-12 /+20 & \approx \geq 974-1006\end{array}$

Beregningerne viser, at det stadig ikke kan udelukkes, at brotømmeret er fældet $i$ år 979 eller 980. Hvis dette er tilfældet, har i hvert fald en del af de træer, der er anvendt til byggeriet, imidlertid haft usædvanligt få splintårringe i forhold til andre egetræer. Ved fældning i år 980 har de træer, hvor- 


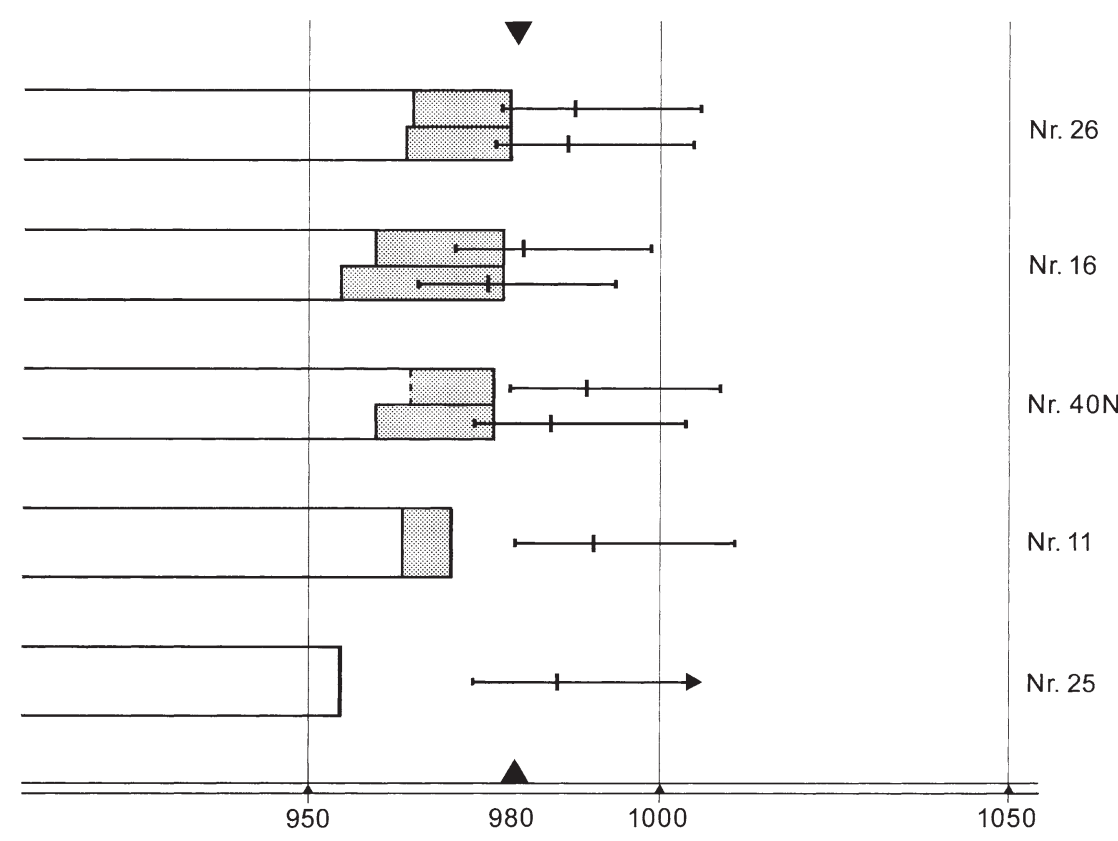

Fig. 3. Bestemmelse af brotømmerets fældningsår. Figuren omfatter de fem daterede prøver, som er af betydning ved fastlæggelsen af tømmerets fældningsår. Hver bjælke repræsenterer ét træ, idet dog kun den yngste del af træernes årringsserie er vist. Splintved er angivet med raster; hvis der er påvist forskelligt antal splintår på forskellige prøver fra træet, er vist såvel det højeste som det laveste antal (for stolpe nr. $40 \mathrm{~N}$ er det laveste antal splintår afgrænset af en stiplet linie som angiver, at der er målt maksimalt 13 splintårringe, dvs. at nogle af de formodede splintår kan være kerneved). Stregerne til højre for bjælkerne angiver fældningsintervallet som beregnet med den anvendte splintstatistik (jf. teksten); det sandsynligste fældningsår er angivet med en lille tværstreg. For stolpe nr. 25, som er uden splintved, er med en pil markeret, at det på figuren viste fældningsinterval er det tidligst mulige, idet prøven fra stolpen også kan mangle en del af kerneveddet.

Determination of the felling year of the bridge timber. The diagram covers the five dated samples of importance for the determination of the felling year of the timber. Each bar represents a tree, although only the last part of the tree ring series from each tree is shown. Sapwood is indicated by shading; if different samples from the post result in different totals for sapwood years, both the highest and the lowest numbers are indicated (in the case of post no. $40 \mathrm{~N}$, the lowest number of years counted in the sapwood is defined by a dotted line, which indicates that a maximum of 13 tree rings were measured in the sapwood - i.e. some of the assumed sapwood years may be heartwood). The lines to the right of the bars indicate the felling interval as calculated with the sapwood statistics used (cf. the text); the probable felling year is indicated by a short line across. As for post no.25, which does not contain any sapwood, an arrow indicates that the felling interval shown in the diagram is the earliest possible, as the post sample may also lack part of the heartwood. 
fra stolpe nr. 11 og nr. 26 stammer, f.eks. haft ca. 17 splintårringe; dette antal findes ifølge splintstatistikken normalt på træer med en alder på omkring 70-80 år, mens træernes faktiske aldre var ca. 274 år og 197 år. De træer, hvorfra stolpe nr. 40N og nr. 25 stammer, har ligeledes flere splintårringe end de fleste træer af deres aldersklasse, men falder dog inden for splintstatistikkens grænser. Kun stolpe nr. 16 stammer formentlig (kun træets minimumsalder kan fastlægges) fra et træ, som ved fældning i 980 havde et antal splintår, der ifølge statistikken svarer til gennemsnittet for træer af den pågældende alder.

At antage at de træer, der er brugt ved bygningen af broen, har haft et atypisk antal splintårringe, er umiddelbart ikke rimeligt; indtil andet er sandsynligjort, må vi ved fastlæggelse af træernes fældningsår gå ud fra, at der er tale om danske træer med normalt udviklet splintved. Vi må derfor konstatere, at det sandsynlige fældningsår for brotømmeret på det foreliggende grundlag ikke kan fastlægges nærmere end til perioden ca. 980-1010, og at Ravning-broen altså kan være opført senere end hidtil antaget.

\section{Konklusion}

De her fremlagte overvejelser viser, at den hævdvundne opfattelse af at de træer, der er anvendt ved bygningen af Ravning-broen, er fældet i år 979 eller 980, ikke har dækning i de dendrokronologiske dateringer. Ikke én af de daterede prøver stammer fra et træ, som med sikkerhed er fældet et af disse år. Med denne konstatering bortfalder også grundlaget for at placere brobyggeriet i en bestemt historisk sammenhæng, sådan som det er forsøgt med udgangspunkt i den hidtidige opfattelse af broens alder. ${ }^{15}$

At argumentere for et andet sandsynligt fældningsår for brotømmeret, beregnet på et stadig usikkert grundlag, er næppe formålstjenligt - især ikke, da muligheden for at opnå et sikrere dateringsgrundlag formentlig foreligger. Takket være udgravernes omtanke er der nemlig, som beskrevet ovenfor, sikret et så stort prøvemateriale fra Ravning-broen, at et større dateringsprogram vil kunne iværksættes. Hvis denne artikel kan bidrage til, at der bliver gennemført en dendrokronologisk undersøgelse af alle de indsamlede træprøver fra broen - heriblandt prøver med splintved, og måske endog med bark - vil den have opfyldt sin hensigt. ${ }^{16}$

\section{NOTER}

1. Bartholin 1973.

2. Ramskou 1977, s. 8. - Undertegnede har som dendrokronolog på Nationalmuseet været involveret i dateringen af Ravning-broen fra først i 1970'erne. Gennem årene har jeg fulgt, hvordan den oprindelige datering blev fremlagt i en stadig fastere form, som 
der efter min mening ikke var dækning for. Efter Mogens Schou-Jørgensens artikel i «Nationalmuseets Arbejdsmark« 1997 orienterede jeg ham skriftligt om mine synspunkter, men disse er desværre ikke blevet taget i betragtning ved senere fremlæggelser af broens alder. Jeg har derfor fundet det relevant at offentliggøre nærværende kommentar. Ansvaret for den misvisende fremlæggelse af dateringen påhviler ikke kun de arkæologer, som har beskæftiget sig med broen, men også de dendrokronologer heriblandt mig selv - der ikke har sørget for, at grundlaget for dateringen i tide blev fremlagt på forsvarlig vis.

3. Jørgensen 1998, s. 7.

4. Hvass 2000 , s. 32.

5. Redegørelsen for prøverne fra broen bygger på en rapport fra undertegnede til Nationalmuseets Naturvidenskabelige Undersøgelser fra 10. februar 2002 med revisioner fra 28. maj 2002.

6. De to stolper fra Vejle Museum betegnes i sagsakterne på Nationalmuseet «KHM 6126« og »KHM 6127«, hvilket umiddelbart forekommer mærkeligt, da «KHM« er den normale forkortelse for Kulturhistorisk Museum i Randers. Efter aftale med Vejle Museum er det dog besluttet, at betegnelserne bibeholdes her.

7. Udover de på Nationalmuseet og i Hamburg målte og daterede prøver er der på Wormianums dendrokronologiske laboratorium undersøgt tre træprøver fra Ravningbroen; disse prøvers herkomst er imidlertid uvis, og da de ikke spiller nogen rolle for broens datering, omtales de ikke yderligere her.

8. De tre udeladte prøvers udgravningsbetegnelser og magasinnumre på NNU er: Pæl 2 spids-top, D 513; stolpe 10, D 523; 1978-14, D 1484.

9. Ramskou 1977.

10. Brev fra Tage E. Christiansen til Nationalmuseets Naturvidenskabelige Afdeling 15. december 1975.

11. Ramskou 1980, 1981; Jørgensen 1997, 1998; Jørgensen og Møller 1999.

12. I et NNU-rapportblad fra 1995, omhandlende de fem prøver, der er målt og dateret på Nationalmuseet (Naturvidenskabelig Afdeling, j. nr. A 5683), anfører Orla H. Eriksen, at disse prøver «fordeler sig i tre grupper. Efter sidste halvdel af 700-tallet [pæl nr. 36], efter midten af 800-tallet [KHM 6127] og efter midten af 900-tallet [KHM 6126, pæl nr. $39 \mathrm{~N}$ og pæl nr. 21], hvilket antyder, at der enten er tale om genbrug eller flere byggefaser i broens opførelse«. Hvis man inddrager de 16 prøver, der er dateret i Hamburg, er det tydeligt, at denne opfattelse ikke er holdbar, jf. fig. 1.

13. Hollstein 1980.

14. Træernes fældningsår er beregnet ud fra oplysningerne i tabel 1, idet der til den yngste kerneårring er lagt det gennemsnitlige antal splintårringe, som træet «burde« have ifølge splintstatistikken. For stolpe 16 er den øvre grænse for fældningsåret angivet som 999, da afstanden fra den ældste målte årring til træets marv er uvis, således at der kun kan beregnes en mindstealder for træet. For stolpe $40 \mathrm{~N}$ er den øvre grænse angivet som 1009, da antallet af splintårringe på den ene af de målte radier kan være mindre end de formodede 13, således at der skal tillægges flere splintår for at nå det teoretisk gennemsnitlige antal. For stolpe 25 er den sandsynlige fældningsperiode angivet som 974-1006, da prøven foruden splinten kan mangle et uvist antal årringe af kerneved.

15. F.eks. Jørgensen 1997, Hvass 2000.

16. Bemærkning om skråstolperne: Ravning-broen omfatter 280 brofag, som hver består af fire lodrette stolper samt yderst på begge sider en stolpe, som skråner ind mod broen; skråstolperne har utvivlsomt primært haft til funktion at stabilisere broen på tværs af længderetningen. Om skråstolperne oplyses, at de er «tildannet med en plant tilhugget side ind mod brofaget, mens ydersiden har bevaret træets naturlige runding« (Jørgensen 1997). På de skråstolper, hvorfra der er udtaget prøver til årringsmåling, er 
ydersidens runding dog menneskeskabt. På en af prøverne er stolpens sider tydeligt planhuggede (stolpe AX), på en anden er der hugfacetter på flere sider (stolpe AY), og på alle prøverne ses, at stolperundingen ikke følger stammens omkreds (se fig. 4 nedenfor); på selve prøverne ses, at stolpernes afrundede sider ikke følger en bestemt årring, men tværtimod skærer igennem årringene. Rundingen på skråstolperne er altså frembragt ved tilhugning. Formålet med at tildanne skråstolperne på denne måde kunne måske være, at de derved beskytter broen bedst muligt mod vand- og ispres. Uanset formålet er den bevidste tilhugning endnu et tegn på den omhu og det forbrug af ressourcer, der er lagt i opførelsen af Ravning-broen.

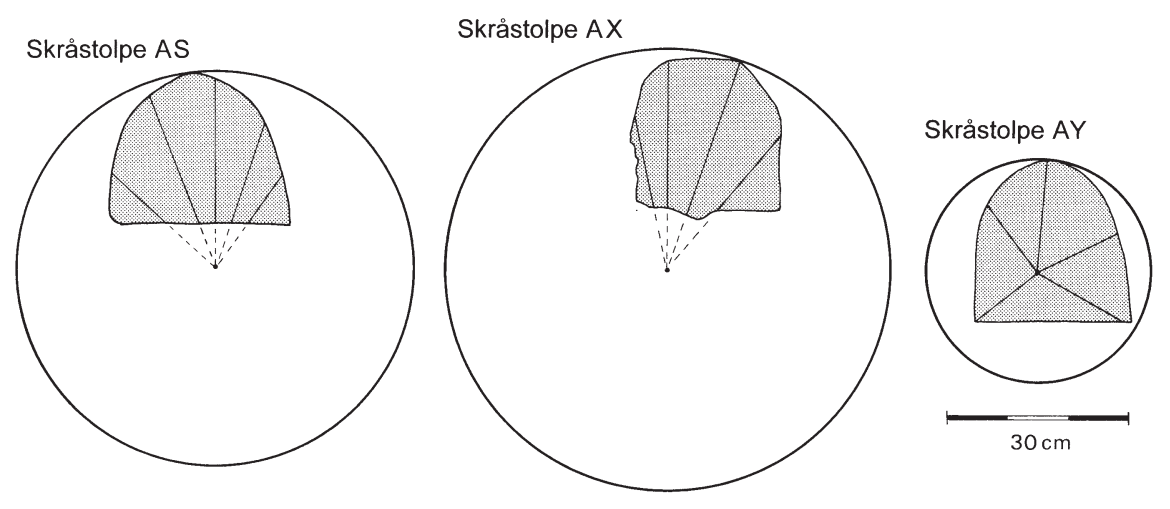

Fig. 4. Tilhugningen af skråstolperne. Tværsnit af tre velbevarede prøver fra skråstolperne, udtaget til dendrokronologisk undersøgelse, men ikke målt eller dateret. Prøverne er indtegnet i stammetværsnit, hvor forløbet af marvstrålerne og beliggenheden af marven (for de prøver, hvor den ikke er bevaret, beregnet ud fra marvstrålernes skæring) også er markeret. Cirklerne angiver en stammetykkelse svarende til de på prøverne bevarede årringe; i virkeligheden har stammerne været tykkere, da prøverne mangler i hvert fald splinten og måske også en del af kerneveddet.

Fig. 4. The shaping of the slanting posts. Cross sections of three well-preserved samples from the slanting posts, taken for dendrochronological investigation, but neither measured nor dated. The samples are drawn as sections through the trunk indicating the course of the medullary rays in the heartwood and the position of the pith. (In samples without heartwood this was calculated from the angles of the medullary rays in the heartwood.) The circles indicate a trunk radius which corresponds with the preserved tree rings on the samples. However, the trunks must in fact have been thicker, as the samples lack all of the sapwood and perhaps also part of the heartwood. 


\section{LITTERATUR}

Bartholin, T. S. 1973: Undersøgelse af muligheden for dendrokronologisk datering af egetræ i Danmark, specielt Sønderjylland. Det Forstlige Forsøgsvecsen i Danmark beretning nr. 265, bd. XXIII, h. 3, s. 217-241.

Hollstein, E. 1980: Mitteleuropäische Eichenchronologie. Trierer Grabungen und Forschungen XI. Mainz am Rhein.

Hvass, Steen 2000: De kongelige monumenter i Jelling - deres historie, forvaltning og formidling. Fonden Kongernes Jelling.

Jørgensen, Mogens Schou 1997: Vikingetidsbroen i Ravning Enge - nye undersøgelser. $\mathrm{Na}$ tionalmuseets Arbejdsmark, s. 74-87.

Jørgensen, Mogens Schou 1998: Den berømte bro. Skalk nr. 5, s. 5-11.

Jørgensen, Mogens Schou \& Jens Tyge Møller 1999: Landskabet som historiens scene. Ravning Enge i vikingetid og middelalder. Vejle Amts Arbog, s. 67-82.

Ramskou, Thorkild 1977: Vikingebroen. Skalk nr. 1, s. 3-9.

Ramskou, Thorkild 1980: Vikingetidsbroen over Vejle å-dal. Nationalmuseets Arbejdsmark, s. 25-32.

Ramskou, Thorkild 1981: Vikingerne som ingeniører. København. 


\section{The age of Ravning Bridge.}

\section{One of Denmark's most reliable dendrochronological datings?}

The excavation of the large Viking Age bridge across the Vejle river valley began at the same time that the dendrochronological dating method came into use in Denmark. In 1977, Thorkild Ramskou, who excavated the bridge, announced that the tree ring dating of the timber showed that the bridge "was built in 979 or at least very close to that year". In 1998, Mogens Schou Jørgensen, who continued the archaeological excavations of the bridge structure after Ramskou's death, stated, "The dating of Ravning Bridge is one of the most reliable from the Danish Viking Age. Almost 100 dendrochronological datings of timber exist, and they point at 979 or 980 as the felling year of the oak trees". In 2000 Steen Hvass gave an even more precise dating for the bridge: "The bridge across Ravning Enge was constructed between October 979 and April 980."

However, the dating is not nearly as scientifically based and precise as these quotations indicate. Around 100 samples from the bridge were taken for dating, but so far tree ring measurements have only been made on 25 of them, and of these only 18 could be dated (table1). Out of these 18, only four samples contained sapwood, and none definitely included the bark ring - i.e. the last tree ring just under the bark. In spite of the quoted statements, not a single investigated sample from the bridge gives a precise year for when the trees were felled and the bridge was built.

The measuring of the tree rings and the dating of the samples was mostly carried out at the dendrochronological laboratory in Hamburg, and the results are completely reliable. The investigation showed that the latest preserved tree ring on the dated samples, which was found on post no. 26, was formed in the year 979, and that the bridge could therefore not have been built until the au- tumn of that year, or later (fig. 1). However, as no bark was preserved on this post, one or more missing tree rings cannot be excluded, and the tree may well have been felled later.

As for the samples with preserved sapwood, the probable felling year of the trees may be determined (although with some uncertainty), since the number of tree rings in the sapwood varies only within a rather limited range. When calculating the year of felling, the Hamburg laboratory assumed that the trees had originally had $20+/-5$ tree rings in the sapwood, as this was considered normal for 1-200 year-old oak trees. The report of the dating which the laboratory gave in 1975 specifies the felling time of the four trees with preserved sapwood as 979-988. This result accords well with Thorkild Ramskou's first announcement about the dating, but it does not provide a basis for claiming that the timber for the bridge was definitely felled in 979 or 980 .

Later, a reconsideration of the dated samples has shown that the trees used for building the bridge were older than first assumed (fig. 2 ). The average age of the trees from which the dated samples stem is almost 300 years, and more trees were close to 500 years old at the time of felling. Consequently, the trees are likely to have had more tree rings in the sapwood than first thought and so they must have been felled later than has hitherto been assumed (as the felling year is found by adding the assumed number of sapwood years to the year of the last tree ring of the heartwood). Calculated from the sapwood statistics used at WM Trædateringslaboratoriet the felling years of the four samples with preserved sapwood lie within the period from 977 to 1009 , whereas the fifth sample without sapwood is assumed to have been felled after 974-1006 (fig. 3). We may therefore conclude 
that using the available material the dating of Ravning Bridge cannot be determined more precisely than "after c.980 and before c.1010", and the bridge may thus be of a later date than assumed so far.

It hardly serves any purpose to argue for a probable felling year of the bridge timber on a basis that is still uncertain. However, thanks to the forethought of the excavators, a large number of not-yet-investigated wood samples from the bridge exist, including samples with sapwood and perhaps with bark. If this article results in a dendrochronological inves- tigation of this material, it will have fulfilled its purpose.

A note on the slanting posts: From the excavation reports it appears that the slanting posts on the outside of each bridge section owed their shape to the preserved natural curve of the wood. However, the samples of the slanting posts that were taken for dendrochronological dating show that the curve on the outside is not natural but results from the wood being hewn into a particular shape (fig. 4). The reason for this shaping of the posts is unknown.

Kjeld Christensen

WM Trædateringslaboratoriet Wormianum - Moesgård Museum

Translated by Annette Lerche Trolle 